Підприємство може використовувати два основні методи ідентифікації ризиків: проактивний та реагуючий. 3 метою виявлення наслідків ризику аналіз ризику трунтується на оцінці двох показників (ймовірності та впливу). Усі існуючі ризики мають бути оброблені. Необхідно проаналізувати можливість усунення джерела ризику, після чого визначити можливості уникнення ризику шляхом припинення діяльності, яка його зумовлює.

Висновки. 3 метою забезпечення своєчасного реагування підприємства на виклики мінливого середовища, підвищення його конкурентоспроможності та економічної безпеки необхідно застосовувати модель управління ризиками, яка повинна відповідати світовим стандартам управління ризиками та ключовим бізнес-проиесам підприємства. Така модель дає змогу ідентифікувати ризики, проаналізувати їх наслідки за двома параметрами (ймовірність та вплив) та встановити процедуру впливу на них.

Ключові слова: ризик, управління ризиками, модель, бізнес-процеси, аналіз ризику, вплив на ризик.

\title{
ZUBKO Tetiana,
}

$\mathrm{PhD}$ (Economics), Associate Professor

of the Department of Economics and Business Finance

of Kyiv National University of Trade and Economics

19, Kyoto str., Kyiv, 02156, Ukraine

E-mail:t.zubko@knute.edu.ua

ORCID ID: https://orcid.org/0000-0002-8950-1797

\section{THE DIAGNOSIS OF ECONOMIC SECURITY OF THE ENTERPRISE}

The essence of economic security of the enterprise and methods of estimation of its level are considered. Methodical approaches to assessing the level of economic security of the enterprise are investigated, and their analysis is carried out. The system of functional components of economic security of the enterprise is proposed and the author's method of estimation of its level is substantiated.

Keywords: economic security, entrepreneurship, enterprise, indicators, hierarchy, thresholds, competitiveness.

(C) Zubko T., 2019 
Зубко Т. Диагностика экономической безопасности предприятия. Рассмотрены суть экономической безопасности предприятия и методы оченки ее уровня. Проанализированы подходы к оченке уровня экономической безопасности предприятия. Предложена система функииональных составляющих экономической безопасности предприятия и обоснована авторская методика оценки ее уровня.

Ключевые слова: экономическая безопасность, предпринимательство, предприятие, индикаторы, иерархия, пороговые значения, конкурентоспособность.

Background. Currently most of enterprises act in incertitude and unpredictability conditions. Precarious political and social economic situation in the country strengthen the level of a risk of decision making and enterprises operation all in all. In the context of a market conditions it is impossible to achieve permanent success in business field if constantly we do not plan its developing effectively, do not accumulate information about own prospects and opportunities about condition of markets, also competitors market position on them so on.

Now under these circumstances formation of the system of diagnostics of economic security of an enterprise for the purpose of an effective managerial decisions approval and future prospects of enterprise developing is becoming important.

Analysis of the last research and publications. Problems of theory, methodology and practical issues of diagnostics of economic security of an enterprise were devoted to a considerable number of scientific works by domestic and foreign economists, among them N. E. Avanesova, G. Andruseac, M. D. Baldzhy, I. M. Kotova, K. I. Tarasova, G.V. Blakyta, A. O. Blyzniuk, Z. S. Varnalii, L. O. Voloshchuk, O. O. Voronkov, K. S. Diachenko, M. I. Kopytko, O. Ya. Kravchuk, P. Ya. Kravchuk, S. M. Laptev, Yu. G. Lysenko, D. K. Nanto, P. A. Poliakov, R. M. Skrynkovskii, O. S. Shumilo [1-16] and other.

Making an analysis of mentioned above scientists' research, we can make a conclusion that economic security of an enterprise is a state of enterprise defensibleness from economic dangers and threats. It is a state when stability of its activity and all kind of resources such as financial, material and immaterial, human resources are not threatened by any negative consequences. At the same time, positively evaluating the results of mentioned above scientists researches, it should be noted that there is currently no generally accepted approach to the method of assessing the level of economic security of the manufacturing and trading enterprise.

Most of the aforementioned studies are devoted to the problem of forming the economic security system of an industrial enterprise, considering the separation of its functional subsystems. However, there is no methodology for assessing the level of economic security in terms of cash flow formation. Among the problems of ensuring the economic security of the company can be mentioned the lack of a common methodology for its comprehensive assessment.

The aim of the article is the investigation of the creation of a system of diagnostics of economic security of the enterprise through the formation of a list of its main indicators. 
Materials and methods. The study of this issue was carried out using theoretical generalization and analysis. The information base of the research is the works of leading scientists, statistical sources, Internet resources.

Results. An analysis of the activity of enterprises shows that they are faced with issues related to the financial, production, technological, investment and information fields of activity. In the conditions of the market it is unrealistic to achieve stable success in business unless to plan its development effectively, not to constantly accumulate information about own prospects and opportunities, about the state of markets, competitors market position. In these conditions, it is now important to form a system of diagnostics of the economic security of an enterprise in order to make effective managerial decisions, to establish further prospects for the development of the enterprise.

The task of economic security is to promote the stable and efficient operation of the enterprise and to realize its full potential for further development.

The economic security system of an enterprise traditionally includes the following components: intellectual and human resources, information, technical and technological, financial, political and environmental, and power $[1 ; 2 ; 6 ; 8 ; 17-19]$.

Taking into account the peculiarities of the manufacturing and trading enterprise, its economic security contains the following functional components:

- security of operational activities (market and technical and technological);

- security of financial activity;

- security of investment activity;

- security of innovative activity;

- intellectual and personnel security.

Assessing the security levels of each functional component, we should consider the security of the logistics operations.

According to the achievements of well-known scientists $[9 ; 10 ; 15 ; 16 ; 20]$, the diagnostics of economic security of an enterprise, as a rule, is performed in the following sequence:

- identification of internal and external factors that determine the economic security of an enterprise (for each of the functional components), analysis and assessment of the degree of their impact;

- calculation of generalized indicators of economic security for each of the functional components;

- calculation of the integral index of economic security of an enterprise;

- development of a set of measures aimed at improving economic security will give us a comprehensive methodology for assessing the level of economic security of an enterprise. In doing so, consideration should be given to their effectiveness.

There are several methods of assessing the level of economic security of an enterprise:

- the assessment of the level of economic security of an enterprise is determined on the basis of the calculation of the aggregate criterion (or integral indicator) by finding and summing up the individual functional 
criteria, which are calculated by comparing the possible magnitude of damage (losses) to the enterprise and the amount of costs for the implementation of measures related to prevention this damage (losses) $[3 ; 13 ; 16]$;

- calculation of functional dependence [5-7];

- use of indicator method $[18 ; 20]$;

- for the express-analysis of the level of security of an enterprise, is being used an approach of using points assesses (rating approach) [10];

- method of determining hierarchical levels of economic security (current, tactical, strategic and general levels) [21];

- graphical [22].

In our opinion, only a balanced combination of these methods, taking into account the industry affiliation of the evaluated enterprise and taking into account the division of indicators into two groups (stimulants and destimulators), allows to create a system of assessing the level of economic security of the enterprise. When constructing functional dependence, apply the method of fuzzy logic theory, which is used to build a model of enterprise activity. The following concepts are used: universal plural; fuzzy plural; function of belonging; linguistic variable; therm-plural; therm-element. That is, the system of economic security indicators can be estimated by methods of fuzzy plurals.

Having analyzed the scientific works $[3 ; 5 ; 7 ; 12-14 ; 17-19 ; 22]$, the indicators of evaluation by functional components were selected and six groups of indicators were compiled.

In accordance with the proposed system of indicators we propose a set of criteria that can be grouped as follows: $X_{1}$ - assessment of the market component of the security of the enterprise, $X_{2}$ - assessment of the technical and technological component, $X_{3}$ - evaluation of the financial component, $X_{4}$ - evaluation of the investment component, $X_{5}$ - evaluation of the innovation component, $X_{6}$ - assessment of the intellectual and personnel component of economic security of the enterprise.

In turn, the complex value of each of these groups can be determined by certain indicators. Thus, the assessment of the market component of the security of an enterprise $X_{1}$ can be estimated by the indicators: the factor of supply of material resources $-X_{11}$, the fulfillment of suppliers by orders $X_{12}$, the degree of compliance with the size of orders $-X_{13}$. The dependency will be as follows:

$$
X_{1}=f_{1}\left(X_{11,} X_{12}, X_{13}\right) .
$$

To evaluate the technical and technological component of economic security $X_{2}$ it is possible to use the indicators production capacity factor $\left(K_{p c}\right)-X_{21}$, wear factor $\left(K_{w}\right)-X_{22}$, returns on assets $(R A)-X_{23}$ :

$$
X_{2}=f_{2}\left(X_{21}, X_{22}, X_{23}\right) \text {. }
$$

The next in the list of functional security components is the financial component. In relation to the meaning of its level scientists' thoughts differ. For example, M. V. Bandura [22] proposes to evaluate financial security on 
the basis of E. Altman's multifactor model. We share the opinion of V. I. Khalina [23] and the indicators of financial security we select the following indicators: the coefficient of autonomy $\left(k_{\text {aut }}\right)-X_{31}$, the coefficient of financing $\left(k_{f i n}\right)-X_{32}$, the ratio of coverage $\left(k_{c o v}\right)-X_{33}$, receivables turnover ratio $\left(k_{r t}\right)-X_{34}$, payables turnover ratio $\left(k_{p t}\right)-X_{35}$, profitability $\left(k_{P}\right)-$ $X 36$. Dependency will look like:

$$
X_{3}=f_{3}\left(X_{31}, X_{32}, X_{33}, X_{34}, X_{35}, X_{36}\right) .
$$

The functional component is investment security that can be estimated on the basis of the turnover ratio of current assets $-X_{41}$, profitability of incomes $-X_{42}$, the level of financial leverage effect $-X_{43}$ :

$$
X_{4}=f_{4}\left(X_{41}, X_{42}, X_{43}\right) \text {. }
$$

The following functional component which is innovative, we will evaluate by the following indicators: the share of employees involved in innovation activity $-X_{51}$, ratio of coverage of capital investments $-X_{52}$, the coefficient of inventive activity $-X_{53}$, the share of realized innovative products in the total volume of products $-X_{54}$, share of research expenditures $-X_{55}$.

Accordingly, the dependence is the following:

$$
X_{5}=f_{5}\left(X_{51}, X_{52}, X_{53}, X_{54}, X_{55}\right) \text {. }
$$

The functioning of the intellectual-personnel subsystem $X_{6}$ can be estimated by the following indicators: staff turnover rate $-X_{61}$, labor productivity level $-X_{62}$, stock-raising of labor $-X_{63}$, the ratio of rationalization activity $-X_{64}$, ratio of highly skilled and skilled workers to the total number of employees - $X_{65}$ :

$$
X_{6}=f_{6}\left(X_{61}, X_{62}, X_{63}, X_{64}, X_{65}\right) .
$$

On the basis of calculated values of groups of indicators the level of economic security of the enterprise is determined:

$$
Y=F\left(X_{1}, X_{2}, X_{3}, X_{4}, X_{5}, X_{6}\right) \text {. }
$$

Note that the set of indicators presented is one of the possible options and can be formed by an expert individually for each individual enterprise, taking into account its specificity. Data of a numerical nature come from the appropriate reporting forms of the enterprise, standards, specifications, etc. Data that cannot be quantified is based on expert judgment.

In order to be able to evaluate and process the linguistic indicators $X_{i j}$, $i=\overline{1, N}, j=\overline{1, M_{i}}$, that characterize an enterprise in terms of its economic security, we form a single scale of five qualitative terms: $V L$ - very low level of $X i j, L$ - low level of $X i j, A$ - average the level of the index $X i j, H-$ high level of the index $X i j, V H-$ a very high level of the index $X i j$.

Using the tools of fuzzy logic, we construct the functions of fuzzy terms for the controlled parameters $X i j, i=\overline{1, N}, j=\overline{1, M_{i}}$ and the output 
variable $Y$. Then we formulate a set of rules for estimating the level of economic security of the enterprise on the basis of independent variables. An expert system based on fuzzy knowledge should include a mechanism of fuzzy logical inference to be able to determine the level of economic security of the enterprise on the basis of all necessary source information received from the user.

The next step in this method is to evaluate the level of indicators. At this stage, the current levels of $X i j, i=\overline{1, N}, j=\overline{1, M}_{i}$ and $Y$ are evaluated based on financial statements and expert judgment for different time periods. The values of the controlled parameters $X i j, i=\overline{\mathbf{1}, N}, j=\overline{1, M}_{i}$, which exactly fall into the intervals $\left[\underline{X}_{i j}, \bar{X}_{i j}\right]$ set for them, will uniquely correspond to their terms. If the value of the criterion is in the interval between the two terms, then it will belong to the term whose belonging function is greater for a given level of the indicator.

As a result, we obtain a linguistic description of the level of economic security of the enterprise and then can evaluate the quality of the results obtained.

Conclusion. The results of the investigation shows that there are different approaches to choosing a methodology for assessing the level of economic security, to defining a system of astimated indicators. A promising area of research in this sphere may be substantiation the use of specific indicators of economic security of an enterprise by its individual components. Diagnosing of the components of economic security is the basis for developing of a set of measures to counter threats and improve the level of security of an enterprise.

\section{REFERENCES}

1. Avanesova, N. E., \& Chuprin, E. S. (2017). Ekonomichna bezpeka pidpryjemstva: sutnistna harakterystyka poniattia [Economic security of the enterprise: an essential characteristic of the concept]. The current state of research and technology in industry, 1, 98-102 [in English].

2. Andruseac, Gabriel (2015). Economic security - new approaches in the context of globalization. CES Working Papers. (Vol. VII). Issue 2. (pp. 232-240) [in English].

3. Baldgi, M. D., Kotova, I. M., \& Tarasova, K. I. (2014). Ekonomichna bezpeka: zabezpechennia, upravlinnia, prohnozuvannia [Economic security: provision, management, forecasting]. Kiev: Huliaieva [in Ukrainian].

4. Blakyta, G., Guliaieva, N., Vavdijchyk, I., Matusova, O. \& Kasianova, A. (2018). Evaluation of investment environment security in Ukraine. Investment Management and Financial Innovations (open-access), 15(4), 320- 331 [in English].

5. Blyzniuk A. O. (2013). Analiz metodyk otsiniuvannia ekonomichnoi bezpeky pidpryiemstva [Analysis of methods for assessing the economic security of the enterprise]. University of Economics and Law "KROK" Higher Educational Institution, 34, 237-245 [in Ukrainian].

6. Varnalij, Z. S., \& Bily'k, R. R. (2018). Ekonomichna bezpeka ta konkurentospromozhnist rehioniv Ukrai'ny [Economic security and competitiveness of Ukrainian regions]. Chernivci: Texnodruk [in Ukrainian]. 
7. Voloshhuk, L. O. (2014). Klasy'fikaciya pidxodiv ta metodiv formuvannya anality'chny'x instrumentiv ocinyuvannya ekonomichnoyi bezpeky' promy'slovogo pidpry'yemstva [Classification of approaches and methods of formation of analytical tools of estimation of economic safety of the industrial enterprise]. Ekonomika: realiyi chasu. Naukovy'j zhurnal-Economy: the realities of time. Scientific journal, 5(15), 224-231. Retrieved from http://economics.opu.ua/ files/archive/2014/n5.html [in Ukrainian].

8. Voronkov, O. O., \& Dyachenko, K. S. (2017). Konceptual'ni zasady' doslidzhennya ekonomichnoyi bezpeky' budivel'nyh pidpry'yemstv [Conceptual bases of research of economic safety of construction enterprises]. Bulletin of Zhytomyr State Technological University, 4(82), 117-124 [in Ukrainian].

9. Kopy'tko, M. I. (2016). Kompleksne zabezpechennya ekonomichnoyi bezpeky' pidpry'yemstv: naukovo-metody'chny'j pidxid [Complex maintenance of economic security of enterprises: scientific and methodological approach]. Project management and production development, 3(55), 127-44. Retrieved from https://cyberleninka.ru/article/n/sistema-ekonomichnoyi-bezpeki-pidpriemstvaponyattya-ta-struktura/viewer [in Ukrainian].

10. Kravchuk, O. Ya., \& Kravchuk, P. Ya. (2014). Diagnosty'ka ta mexanizm zabezpechennya korporaty'vnoyi bezpeky' pidpry'yemstva [Diagnosis and mechanism of corporate corporate security]. Lucz'k: Nadsty'r'ya [in Ukrainian].

11. Laptyev, S. M., Al'kema, V. G., Sidak, V. S., \& Kopy'tko, M. I. (2017). Kompleksne zabezpechennya ekonomichnoyi bezpeky' pidpry'yemstv [Integrated Assurance of Economic Security of Enterprises]. Kyiv: Krok [in Ukrainian].

12. Ly'senko, Yu. G. (2018). Modernizaciya sy'stemy' upravlinnya ekonomichnoyu bezpekoyu nacional 'noyi ekonomiky': metodologiya, indy'katory' ta instrumenty' [Modernization of the economic security management system of the national economy: methodology, indicators and tools]. Poltava: VNZ Ukoopspilky' "Poltav. un-t ekonomiky' i torgivli" (PUET) [in Ukrainian].

13. Nanto, D. K. (2011), Economics and National Security: Issues and Implications for U.S. Policy, Congressional Research Service, Retrieved from https://www.fas.org/ sgp/crs/natsec/R41589.pdf [in English].

14. Polyakov P. A. (2017). Koncepciya upravlinnya ekonomichnoyu bezpekoyu vitchy'znyany'x pidpry'yemstv [The concept of economic security management of domestic enterprises]. Scientific Bulletin of Kherson State University. (Vol.1), 24. 135-139 [in Ukrainian].

15. Skryn'kovs'kij, R. M. (2017). Ekonomichna bezpeka pidpryjemstva [Economic security of the enterprise: essence, classification and system of diagnostics]. Nikolaev National University. V.O. Sukhomlinsky. (Vol. 3). (pp. 414-418) [in Ukrainian].

16. Shumilo, O. S. (2015). Skladovi ekonomichnoi' bezpeky pidpryjemstv rozdribnoi' torgivli [Components of economic security of retailers]. Ekonomichnyj prostir-Economic space, 100, 205-217 [in Ukrainian].

17. Blank, I. A. (2004). Upravlenye fynansovoi bezopasnostiu predpryiatyia [Management of financial security of the enterprise]. Kyiv: Эlha, Nyka-Tsentr [in Russian].

18. Vasy'l'civ, T. G., Voloshy'n, V. I., Bojkevy'ch, O. R., \& Karkavchuk, V. V. (2012). Finansovo-ekonomichna bezpeka pidpry'yemstv Ukrayiny': strategiya ta mexanizmy' zabezpechennya [Economic security and competitiveness of Ukrainian regions]. L'viv: LKA [in Ukrainian].

19. Get'man, O. O., \& Shapoval, V. M. (2007). Ekonomichna diagnosty'ka [Economic diagnostics]. Kyiv: Center for Educational Literature [in Ukrainian]. 
20. Logutova, T. G., \& Kamyishnikova, E. V. (2013). Ekonomicheskaya bezopasnost promyishlennyih predpriyatiy [Economic security of industrial enterprises]. Mariupol: GVUZ "PGTU" [in Ukrainian].

21. Dovbnya, S. B., \& Gichova, N. Yu. (2008). Diagnosty'ka rivnya ekonomichnoï bezpeky' pidpry'yemstva [Diagnosis of the level of economic security of the enterprise] Finance of Ukraine, 4, 88-97 [in Ukrainian].

22. Krasnova, V. V., \& Bandura, M. B. (2013). Ekonomichna diagnosty'ka [Economic diagnostics]. Donecz'k: DonNU [in Ukrainian].

23. Khalina, V. Ju. (2014). Metodychnyj pidhid do ocinky rivnja ekonomichnoi' bezpeky pidpryjemstva [Methodical approach to assessing the level of economic security of the enterprise]. Ekonomichna bezpeka I pidpryjemnyctvo Economic security and entrepreneurship, 1(53), 173-181 [in Ukrainian].

The article submitted to editor's office on 03.12.2019.

\section{Зубко Т. Діагностика економічної безпеки підприємства.}

Постановка проблеми. Більшість підприємств наразі праџюють в умовах невизначеності та непередбачуваності. Нестабільна політична і соиіально-економічна ситуаиія в країні посилюють ступінь ризику прийняття рімень і функиіонування підприємств загалом. За иих умов важливого значення набуває формування системи діагностики економічної безпеки підприємства з метою ухвалення ефективних управлінських рішень, встановлення подальших перспектив розвитку підприємства.

Аналіз останніх досліджень і публікацій показав, що попри наявність окремих наукових доробок, залишається невирішеною важлива науково-практична проблема щодо загальноприйнятого підходу до методики оцінки рівня економічної безпеки, а саме виробничо-торговельного підприємства.

Метою статті є дослідження питання створення системи діагностики економічної безпеки підприємства через формування переліку його основних показників.

Матеріали та методи. Вивчення зазначеної наукової проблеми проведено із застосуванням теоретичного узагальнення й аналізу. Інформаційною базою дослідження є праиі провідних науковиів, статистичні джерела, інтернет-ресурси.

Результати дослідження. Результати аналізу діяльності підприємств свідчать, що перед ними постають питання, пов'язані з фінансовою, виробничою, технологічною, інвестииійною та інформаційною сферами діяльності. В умовах ринку нереально домогтися стабільного успіху в бізнесі, якщо не планувати ефективно його розвиток, не акумулювати постійно інформацію про власні перспективи й можливості, стан ринків, становище на них конкурентів тощо. Наразі важливого значення набуває формування системи діагностики економічної безпеки підприємства з метою ухвалення ефективних управлінських рішень, встановлення подальших перспектив розвитку підприємства.

Розглянуто сутність економічної безпеки підприємства і методи оцінки ї̈ рівня. Досліджено підходи до оиінки рівня економічної безпеки підприємства, проведено їх аналіз. Запропоновано систему функиіональних складових економічної безпеки підприсмства та обтрунтовано авторську методику очінки ії рівня.

Висновки. Нині існують різні підходи до вибору методики оцінки рівня економічної безпеки, визначення системи оціночних показників. Перспективним напрямком досліджень у иій сфері може бути обтрунтування використання конкретних показників економічної безпеки підприємства за окремими ї̈ складовими. Діагностування складових економічної безпеки є основою для розробки комплексу заходів протидї загрозам та підвищення рівня захищеності підприємства.

Ключові слова: економічна безпека, підприємництво, підприємство, індикатори, ієрархія, порогові значення, конкурентоспроможність. 